\title{
LINEATION IN THE NORTH-WEST HIGHLANDS OF SCOTLAND
}

Sir,--Study of the lineation in metamorphic rocks of the Northwest Highlands of Scotland was initiated by the original geological surveyors, who mapped in many places a "direction of stretching of the particles of foliated rocks ". Analysis of the fabric (Phillips, 1937, 1945) shows that, over a wide area east of the Moine Thrust in rocks originally mapped as belonging to the Moine Series, this southeasterly plunging lineation marks the direction of the $b$-axis of the girdle fabric of a B-tectonite-the lineation is a Striemung of German authors. Richey \& Kennedy (1939) have demonstrated that in the Morar district an upper series, referred to the Moine Schists, rests unconformably on a lower group containing both ortho- and paragneisses which they have provisionally named the Sub-Moine Series. Until the mapping of these two divisions is carried further north it is not clear how far the rocks in which I have examined the lineation may belong to the Sub-Moine Series, and it therefore seems advisable at present to refer to these rocks non-committally as " lineated schists east of the Moine Thrust".

It has been widely accepted by structural petrologists, following mainly the pioneer work of Sander, that a Striemung is induced by displacements acting in a direction approximately normal to it, but this correlation has at times been called in question (Martin, 1935, 1936, 1939 ; Strand, 1944 ; Kvale, 1941 etc. ; E. Cloos, 1944, 1946,). A north-west south-east lineation, which is parallel to the $b$-axis of a girdle fabric, is widely developed on the south-east flank of the Caledonides in Norway, and has been interpreted (Kvale, Strand) as a true "direction of stretching" developed during the Caledonian movements ; where it is found in rocks of proved pre-Cambrian age, these rocks are held to have been completely recrystallized during the Caledonian orogeny.

I have recently examined the microfabric of a number of orthogneisses and hornblende schists from the Foreland region of the North-west Highlands (rocks which are coloured on the maps of the Geological Survey as Lewisian), and find that here also the lineation is parallel to the $b$-axis of a girdle fabric. The lineation strikes predominantly north-west south-east. It is conceivable that within the Scottish Caledonides there may be included metamorphosed representatives of Lewisian and other Sub-Moine rocks, Moine, Torridonian, and Lower Palaeozoic rocks, and detailed examination of their fabric should help to provide some evidence for their eventual separation. Further research is necessary to establish how far (if at all) the south-easterly plunging lineation of the " lineated schists east of the Moine Thrust" can be correlated with the similar lineations in rocks of the Foreland. 
and thus be interpreted as a relict fabric. It is important, meanwhile, to record that there is an extensive development in Scotland of a north-west south-east lineation which apparently cannot have been induced by the Caledonian movements, but which must be related to a pre-Torridonian orogeny, since these lineated rocks of the Foreland are overlain by unmetamorphosed Torridonian and Cambrian sediments.

F. C. Phillips.

CAMrRiDge.

December, 1946.

Cloos, E., 1944. Correlation of lineation with rock-movement. Trans. Amer. Geophys. Union, 660-662.

1946. Lineation. Geol. Soc. Amer., Memoir 18, 1, 46, etc.

Kvale, A., 1941. Petrografisk-tektoniske undersøkelser i fjellkjeden mellom Bergens-buene og Voss. Norsk Geol. Tidsskr., 21, 191-197.

1944. Skyvning og friksjon. Norsk Geol. Tidsskr., 24, 32-39.

1945. Petrofabric analysis of a quartzite from the Bergsdalen Quadrangle, Western Norway. Norsk Geol. Tidsskr., 25, 193-215.

1945. Petrologic and structural studies in the Bergsdalen Quadrangle. Part I, Petrography. Bergens Museums Arbok, Naturvitenskapelig rekke, Nr. 1.

Martin, H., 1935. Über Striemung, Transport und Gefüge. Geol. Rundschau, 26, 103-108.

1936. Uber Striemung, Transport und Gefüge (zu B. Sander's Mitteilung . . . ). Geol. Rundschau, 27, 303-304.

1939. Die Post-Archäische Tektonik im südlichen Mittelschweden. Neues Jahrb. Min., Beil. Bd. 82, Abt. B, 69.

Phillips, F.. C., 1937. A fabric study of some Moine schists . . Quart. Journ. Geol. Soc., 93, 581-616.

- 1945. The micro-fabric of the Moine Schists. Geol. Mag., 82, 205-220.

RicheY, J. E., and KenNedy, W. Q., 1939. The Moine and Sub-Moine Series of Morar, Inverness-shire. Bull. Geol. Surv. Gt. Brit., No, 2, $26-45$.

STRAND, T., 1944. Structural petrology of the Bygdin Conglomerate. Norsk Geol. Tidsskr., 24, 14-31.

\section{CRYSTALLIZATION OF PLUTONIC AND HYPABYSSAL ROCKS}

SIR,-I should like to reply to Mr. McIntyre's letter appearing in the last number of the Geological Magazine. I will deal with the points he raised in order:-

1. If members of a series of related minerals cease to crystallize out one after the other, a eutectic relationship between the individual minerals is excluded. Obviously eutectics and reaction points can occur in the same system, and a "concealed maximum " is associated with an incongruent melting compound which gives rise to a reaction point in the system. I am afraid I assumed my readers would be familiar with the more elementary types of phase diagram.

2. As Mr. McIntyre is so interested, I can indicate the kind of phase 